\title{
Sulfur, fresh cassava root, and urea independently enhanced gas production, ruminal characteristics, and in vitro degradability
}

Phussorn Sumadong

Khon Kaen University

Anusorn Cherdthong ( $\nabla$ anusornc@kku.ac.th )

Khon Kaen University

Sarong So

Khon Kaen University

Metha Wanapat

Khon Kaen University

\section{Research Article}

Keywords: Sulfur, Hydrogen cyanide, Gas production, Ammonia nitrogen, Propionic acid, Degradability

Posted Date: April 29th, 2021

DOI: https://doi.org/10.21203/rs.3.rs-463093/v1

License: (c) (i) This work is licensed under a Creative Commons Attribution 4.0 International License. Read Full License 


\section{Abstract}

Background: Cassava root (FCR) is one of the main energy source ingredients for ruminant and low price. The limitation of FCR utilization is due to the presence of hydrogen cyanide $(\mathrm{HCN})$, which is toxic when animals, especially ruminants. The study aimed to evaluate the effect of sulfur, urea, and FCR at various levels on gas production, ruminal fermentation, and in vitro degradability. The study hypothesized that: 1) sulfur, urea, and FCR have no interaction effect and 2) effect of FCR and urea is related to sulfur addition.

Results: The study aimed to elucidate the optimum level of elemental sulfur, fresh cassava root (FCR), and urea and their effect on gas production, ruminal fermentation, thiocyanate concentration, and in vitro degradability. A $3 \times 2 \times 4$ in a completely randomized design were conducted. Factor A was level of sulfur at $0 \%, 1 \%$, and $2 \%$ of concentrate dry matter (DM), factor $B$ was level of urea at $2 \%$ and $4 \%$ of concentrate DM, and factor $C$ was level of the FCR at $0,200,300$, and $400 \mathrm{mg}$ of the total substrate. The study found that elemental sulfur, urea, and FCR had no interaction effect on the kinetics of gas, ruminal fermentation, hydrogen cyanide $(\mathrm{HCN})$, and in vitro degradability. Elemental sulfur supplementation $(P<0.05)$ significantly increased the gas produced from an insoluble fraction (b), in vitro DM degradability and either neutral detergent fiber or acid detergent fiber degradability, and propionate (C3) concentration while decreased the ruminal HCN concentration. Urea levels showed a $(P<0.05)$ significant increase of the potential extent of gas production, ruminal $\mathrm{NH}_{3}-\mathrm{N}$, and total volatile fatty acid (VFA). FCR supplementation $(P<0.05)$ significantly increased the gas produced from an immediate soluble fraction (a), gas produced from insoluble fraction, gas production rate constant, total VFA, C3 concentration, and $\mathrm{HCN}$ while decreased ruminal $\mathrm{pH}$, acetate, and butyrate concentration. It could be concluded that $2 \%$ elemental sulfur, $4 \%$ urea, and $300 \mathrm{mg}$ FCR showed a greater effect on gas production, ruminal fermentation, and $\mathrm{HCN}$ reduction.

Conclusions: The study found that elemental sulfur, urea, and FCR had no interaction effect on the kinetics of gas, total gas, ruminal fermentation, and $\mathrm{HCN}$ concentration. It could be concluded that $2 \%$ elemental sulfur, $4 \%$ urea, and $300 \mathrm{mg}$ FCR showed a greater effect on gas production, ruminal fermentation, and $\mathrm{HCN}$ reduction.

\section{Background}

Cassava root (FCR) is one of the main energy source ingredients for ruminant [1] and low price. The limitation of FCR utilization is due to the presence of hydrogen cyanide $(\mathrm{HCN})$, which is toxic when animals, especially ruminants, consume more than $200 \mathrm{mg} / \mathrm{kg}$ fresh matter [2, 3]. FCR contains 90 to 114 $\mathrm{mg} / \mathrm{kg}$ of $\mathrm{HCN}$ [2]. The HCN toxicity can be reduced by sun-drying [1]; however, it is not an appropriate method during the rainy season. A chemical method, using sulfur, has been tested and shown to increase thiocyanate concentration, which is less toxic for the host $[2,4,5]$. Briefly, thiocyanate is the product of dependent-sulfur rhodanese enzyme presented in the rumen break-down and subsequently excreted out of the body via urine [6, 7]. Besides its toxicity, FCR has low crude protein (CP) content (2 to $3 \%$ ) [8]. Common non-protein nitrogen, urea, is added into the diet to increase CP content and use as a nitrogen 
source for microbial protein synthesis in the rumen [9]. Sulfur is closely related to nitrogen metabolism. Therefore, the optimum level of sulfur supplementation in the diet containing urea is necessary to elucidate. In lambs, improvement of protein utilization efficiency was firstly reported by Johnson et al. [10] when sulfur was added into the diet containing cassava. An in vitro study of Promkot et al. [6] similarly reported to significantly increase true protein digestibility when sulfur of reduced-sodium sulfide nonahydrate was added into a substrate containing cassava foliage and hay. However, a subsequent study by Promkot and Wanapat [7] showed no significant effect of sulfur supplementation on protein digestibility in dairy cows' diets containing both fresh cassava foliage and cassava hay. In beef cattle, Cherdthong et al. [2] showed no significant effect of feed-block containing sulfur on protein digestibility in a diet composed of the FCR. Supapong and Cherdthong [5] found no significant effect of sulfur in combination with urea on digestibility of dairy cows fed a fermented total mixed ration containing FCR. Insufficient sulfur supply can cause low digestion of dietary nutrients and microbial protein synthesis [11] and its form might significantly affect microbial metabolism in the rumen. NRC [12] stated that requirement of sulfur for ruminants might be increased for detoxifying $\mathrm{HCN}$. However, the evaluation effect of high sulfur addition into a substrate containing FCR as a source of HCN is still limited, and study on the effect of sulfur, urea, and FCR and their interaction on gas production, rumen fermentation, and in vitro digestibility has not yet been studied.

The study aimed to evaluate the effect of sulfur, urea, and FCR at various levels on gas production, ruminal fermentation, and in vitro degradability. The study hypothesized that: 1) sulfur, urea, and FCR have no interaction effect and 2) effect of FCR and urea is related to sulfur addition.

\section{Results}

\section{Dietary nutrients}

The main energy source of the study diets was dominated by cassava chips. The concentrate contains 12 to $18 \% \mathrm{CP}$ as mainly dominated by urea supplementation at $2 \%$ and $4 \%$. The FCR used in this study contains $104.6 \mathrm{mg} / \mathrm{kg}$ of HCN as shown in Table 1. 
Table 1

Ingredients and chemical composition of concentrate, fresh cassava roots (FCR) and rice straw (\% dry matter basis)

\begin{tabular}{|c|c|c|c|c|c|c|c|c|}
\hline \multirow[t]{2}{*}{ Item } & \multicolumn{2}{|c|}{$0 \%$ Sulfur } & \multicolumn{2}{|c|}{$1 \%$ Sulfur } & \multicolumn{2}{|c|}{$2 \%$ Sulfur } & \multirow[t]{2}{*}{ FCR } & \multirow{2}{*}{$\begin{array}{l}\text { Rice } \\
\text { straw }\end{array}$} \\
\hline & $\begin{array}{l}2 \% \\
\text { Urea }\end{array}$ & $\begin{array}{l}4 \% \\
\text { Urea }\end{array}$ & $\begin{array}{l}2 \% \\
\text { Urea }\end{array}$ & $\begin{array}{l}4 \% \\
\text { Urea }\end{array}$ & $\begin{array}{l}2 \% \\
\text { Urea }\end{array}$ & $\begin{array}{l}4 \% \\
\text { Urea }\end{array}$ & & \\
\hline \multicolumn{9}{|c|}{ Ingredients, \% dry matter (DM) } \\
\hline Cassava chip & 65 & 63 & 64 & 63 & 63 & 61 & & \\
\hline Rice bran & 10 & 10 & 10 & 10 & 10 & 10 & & \\
\hline Soybean meal & 5 & 5 & 5 & 5 & 5 & 5 & & \\
\hline $\begin{array}{l}\text { Palm kernel } \\
\text { meal }\end{array}$ & 15 & 15 & 15 & 14 & 15 & 15 & & \\
\hline Premix $^{1}$ & 1 & 1 & 1 & 1 & 1 & 1 & & \\
\hline Sulfur & 0 & 0 & 1 & 1 & 2 & 2 & & \\
\hline Urea & 2 & 4 & 2 & 4 & 2 & 4 & & \\
\hline Salt & 1 & 1 & 1 & 1 & 1 & 1 & & \\
\hline Molasses & 1 & 1 & 1 & 1 & 1 & 1 & & \\
\hline \multicolumn{9}{|c|}{ Chemical composition } \\
\hline Dry matter, \% & 93.6 & 93.6 & 93.6 & 93.6 & 93.6 & 93.6 & 33.0 & 94.7 \\
\hline \multicolumn{9}{|c|}{ - $\%$ DM-- } \\
\hline Organic matter & 92.8 & 92.8 & 92.8 & 92.8 & 92.7 & 92.7 & 98.5 & 93.3 \\
\hline Crude protein & 12.4 & 18.1 & 12.2 & 18.1 & 12.5 & 18.2 & 2.4 & 2.7 \\
\hline NDF & 12.0 & 12.1 & 12.2 & 12.1 & 12.1 & 12.3 & 53.0 & 66.7 \\
\hline ADF & 8.0 & 8.2 & 8.2 & 8.3 & 8.3 & 8.3 & 31.4 & 43.5 \\
\hline $\mathrm{HCN}, \mathrm{mg} / \mathrm{kg}$ & - & - & - & - & - & - & 104.6 & - \\
\hline $\begin{array}{l}{ }^{1} \text { Premix compc } \\
\text { Zn: } 40 \text { g; Mn: } 40 \\
\text { means acid det }\end{array}$ & $\begin{array}{l}\text { ed of v } \\
\text {; Co: } 0 \\
\text { jent fil }\end{array}$ & $\begin{array}{l}\text { in A: } 1 \\
\text { Cu: } 10 \\
\text { ICN m }\end{array}$ & $\begin{array}{l}0,000 \text { I } \\
\text { e: } 0.1 \\
\text { hydro }\end{array}$ & $\begin{array}{l}\operatorname{amin} \\
.5 \mathrm{~g} . \\
\text { cyanid }\end{array}$ & $\begin{array}{l}0,000 \mathrm{II} \\
\text { means }\end{array}$ & $\begin{array}{l}\operatorname{amin} \mathrm{D} \\
\text { tral det }\end{array}$ & $\begin{array}{l}00,000 \\
\text { nt fiber, }\end{array}$ & $\begin{array}{l}\text {; Fe: } 50 \\
\text { DF }\end{array}$ \\
\hline
\end{tabular}

\section{Gas kinetics and total gas}

Table 2 shows the kinetics (a, b, c, and a $+b)$ of gas and cumulative gas at $96 \mathrm{~h}$ of incubation. The sulfur, urea, and FCR showed no significant interaction effect on the kinetics of gas and total gas. Sulfur 
supplementation did not affect total gas and kinetics of gas except gas produced from insoluble fraction (b). Increasing sulfur significantly increased the b value compared to the control; however, $1 \%$ and $2 \%$ sulfur supplementation did not differ (Table 2). 
Table 2

Effect of elemental sulfur (S), urea (U), and fresh cassava root (FCR) on kinetics of gas and gas production at $96 \mathrm{~h}$ of incubation

\begin{tabular}{|c|c|c|c|c|c|c|c|c|}
\hline \multirow[t]{2}{*}{ Treatments } & \multirow{2}{*}{$\begin{array}{l}S \\
\text { (\%) }\end{array}$} & \multirow{2}{*}{$\begin{array}{l}\text { U } \\
\text { (\%) }\end{array}$} & \multirow{2}{*}{$\begin{array}{l}\text { FCR } \\
(\mathrm{mg})\end{array}$} & \multicolumn{4}{|c|}{ Kinetics of gas } & \multirow{2}{*}{$\begin{array}{l}\text { Gas production } \\
\mathrm{ml} / \mathrm{g}\end{array}$} \\
\hline & & & & a & b & c & $a+b$ & \\
\hline T1 & 0 & 2 & 0 & -4.53 & 86.05 & 0.052 & 81.51 & 80.92 \\
\hline T2 & 0 & 4 & 0 & -5.71 & 95.65 & 0.053 & 89.94 & 89.61 \\
\hline T3 & 1 & 2 & 0 & -3.25 & 91.53 & 0.052 & 98.28 & 90.41 \\
\hline T4 & 1 & 4 & 0 & -5.20 & 88.84 & 0.050 & 83.64 & 83.91 \\
\hline T5 & 2 & 2 & 0 & -3.42 & 89.60 & 0.051 & 86.18 & 85.52 \\
\hline T6 & 2 & 4 & 0 & -6.34 & 82.63 & 0.049 & 76.29 & 86.50 \\
\hline T7 & 0 & 2 & 200 & -8.13 & 104.20 & 0.078 & 96.07 & 105.95 \\
\hline T8 & 0 & 4 & 200 & -7.32 & 102.11 & 0.075 & 94.78 & 94.38 \\
\hline T9 & 1 & 2 & 200 & -9.78 & 109.43 & 0.089 & 99.65 & 99.64 \\
\hline T10 & 1 & 4 & 200 & -8.58 & 104.78 & 0.076 & 96.20 & 94.80 \\
\hline T11 & 2 & 2 & 200 & -9.37 & 106.90 & 0.080 & 97.54 & 97.51 \\
\hline T12 & 2 & 4 & 200 & -9.64 & 107.32 & 0.082 & 97.68 & 102.62 \\
\hline T13 & 0 & 2 & 300 & -10.05 & 118.63 & 0.090 & 108.58 & 122.35 \\
\hline T14 & 0 & 4 & 300 & -11.30 & 122.37 & 0.093 & 111.06 & 130.75 \\
\hline T15 & 1 & 2 & 300 & -11.24 & 119.00 & 0.091 & 107.76 & 113.20 \\
\hline T16 & 1 & 4 & 300 & -11.11 & 123.97 & 0.095 & 112.86 & 113.86 \\
\hline T17 & 2 & 2 & 300 & -11.79 & 127.79 & 0.097 & 116.00 & 115.68 \\
\hline T18 & 2 & 4 & 300 & -12.08 & 120.93 & 0.093 & 108.68 & 116.62 \\
\hline T19 & 0 & 2 & 400 & -11.00 & 102.46 & 0.075 & 91.46 & 98.45 \\
\hline T20 & 0 & 4 & 400 & -11.66 & 105.56 & 0.077 & 93.89 & 94.87 \\
\hline T21 & 1 & 2 & 400 & -11.56 & 110.58 & 0.087 & 99.02 & 101.96 \\
\hline T22 & 1 & 4 & 400 & -12.00 & 103.93 & 0.074 & 91.39 & 93.73 \\
\hline
\end{tabular}

a means the gas production from the immediately soluble fraction $(\mathrm{mL})$; $b$ means the gas production from the insoluble fraction $(\mathrm{mL})$; $c$ means the gas production rate constant for the degradable fraction $b ; a+b$ means the potential extent of gas production $(\mathrm{mL})$

a,b,c means within column showed with different superscript letter accepted significantly different 


\begin{tabular}{|c|c|c|c|c|c|c|c|c|}
\hline \multirow[t]{2}{*}{ Treatments } & \multirow{2}{*}{$\begin{array}{l}S \\
\text { (\%) }\end{array}$} & \multirow{2}{*}{$\begin{array}{l}\text { U } \\
\text { (\%) }\end{array}$} & \multirow{2}{*}{$\begin{array}{l}\text { FCR } \\
(\mathrm{mg})\end{array}$} & \multicolumn{4}{|c|}{ Kinetics of gas } & \multirow{2}{*}{$\begin{array}{l}\text { Gas production } \\
\mathrm{ml} / \mathrm{g}\end{array}$} \\
\hline & & & & a & b & c & $a+b$ & \\
\hline T23 & 2 & 2 & 400 & -11.27 & 110.64 & 0.080 & 99.37 & 106.31 \\
\hline T24 & 2 & 4 & 400 & -12.08 & 110.60 & 0.081 & 98.51 & 104.51 \\
\hline SEM & & & & 1.84 & 12.20 & 0.015 & 9.87 & 12.40 \\
\hline \multicolumn{9}{|l|}{ S (\%) } \\
\hline 0 & & & & -8.71 & $104.62^{b}$ & 0.07 & 100.91 & 102.16 \\
\hline 1 & & & & -9.08 & $106.44^{a}$ & 0.07 & 99.23 & 98.93 \\
\hline 2 & & & & -9.49 & $107.05^{a}$ & 0.07 & 131.65 & 101.89 \\
\hline P-Value & & & & 0.081 & 0.016 & 0.110 & 0.412 & 0.245 \\
\hline \multicolumn{9}{|l|}{ U (\%) } \\
\hline 2 & & & & -8.78 & 106.40 & 0.07 & $100.64^{b}$ & 101.49 \\
\hline 4 & & & & -9.41 & 105.67 & 0.07 & $142.35^{\mathrm{a}}$ & 100.50 \\
\hline P-Value & & & & 0.175 & 0.282 & 0.086 & $\nabla 0.0001$ & 0.324 \\
\hline \multicolumn{9}{|l|}{ FCR (mg) } \\
\hline 0 & & & & $-4.74^{a}$ & $89.05^{c}$ & $0.05^{\mathrm{c}}$ & 86.14 & $86.14^{c}$ \\
\hline 200 & & & & $-8.80^{\mathrm{b}}$ & $105.79^{b}$ & $0.08^{b}$ & 99.49 & $99.15^{\mathrm{b}}$ \\
\hline 300 & & & & $-11.26^{c}$ & $122.11^{\mathrm{a}}$ & $0.09^{a}$ & 115.06 & $118.72^{\mathrm{a}}$ \\
\hline 400 & & & & $-11.59^{c}$ & $107.20^{b}$ & $0.08^{b}$ & 189.19 & $99.97^{b}$ \\
\hline P-Value & & & & $\varangle 0.0001$ & $₫ 0.0001$ & $\bowtie 0.0001$ & 0.367 & $\bowtie 0.0001$ \\
\hline \multicolumn{9}{|l|}{ Interaction } \\
\hline$S * U$ & & & & 0.949 & 0.103 & 0.558 & 0.117 & 0.217 \\
\hline$S * F C R$ & & & & 0.738 & 0.465 & 0.764 & 0.599 & 0.232 \\
\hline U*FCR & & & & 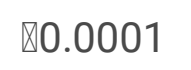 & $\nabla 0.0001$ & $\nabla 0.0001$ & $\triangle 0.0001$ & $\bigotimes 0.0001$ \\
\hline
\end{tabular}

a means the gas production from the immediately soluble fraction $(\mathrm{mL})$; $b$ means the gas production from the insoluble fraction $(\mathrm{mL})$; $c$ means the gas production rate constant for the degradable fraction $b ; a+b$ means the potential extent of gas production $(\mathrm{mL})$

a,b,c means within column showed with different superscript letter accepted significantly different 


\begin{tabular}{|c|c|c|c|c|c|c|c|c|}
\hline \multirow[t]{2}{*}{ Treatments } & \multirow{2}{*}{$\begin{array}{l}S \\
(\%)\end{array}$} & \multirow{2}{*}{$\begin{array}{l}U \\
(\%)\end{array}$} & \multirow{2}{*}{$\begin{array}{l}\text { FCR } \\
(\mathrm{mg})\end{array}$} & \multicolumn{4}{|c|}{ Kinetics of gas } & \multirow{2}{*}{$\begin{array}{l}\text { Gas production } \\
\mathrm{ml} / \mathrm{g}\end{array}$} \\
\hline & & & & a & b & c & $a+b$ & \\
\hline$S * U * F C R$ & & & & 0.428 & 0.776 & 0.888 & 0.893 & 0.076 \\
\hline \multicolumn{9}{|c|}{$\begin{array}{l}\text { a means the gas production from the immediately soluble fraction }(\mathrm{mL}) ; b \text { means the gas production } \\
\text { from the insoluble fraction }(\mathrm{mL}) ; c \text { means the gas production rate constant for the degradable } \\
\text { fraction } b ; a+b \text { means the potential extent of gas production }(\mathrm{mL})\end{array}$} \\
\hline
\end{tabular}

\section{Ruminal fermentation, hydrogen cyanide concentration, and protozoal number}

The effect of elemental sulfur, $\mathrm{FCR}$, and urea on $\mathrm{pH}, \mathrm{NH}_{3}-\mathrm{N}, \mathrm{HCN}$, and protozoa were shown in Table 3. Elemental sulfur, urea, and $\mathrm{FCR}$ had no significant interaction effect on $\mathrm{pH}, \mathrm{NH}_{3}-\mathrm{N}, \mathrm{HCN}$, and protozoal number. The interaction effect between elemental sulfur, FCR, and urea has never been elucidated until the present. Elemental sulfur supplementation significantly decreased the HCN concentration but did not affect the $\mathrm{pH}, \mathrm{NH}_{3}-\mathrm{N}$, and protozoal number. Sulfur supplementation significantly reduced $\mathrm{HCN}$ when compared to the control; however, $1 \%$ vs $2 \%$ sulfur supplementation did not differ for the HCN reduction. 
Table 3

Effect of elemental sulfur (S), urea (U), and fresh cassava root (FCR) on rumen fermentation parameters, hydrogen cyanide (HCN), and protozoal number

\begin{tabular}{|c|c|c|c|c|c|c|c|}
\hline Treatments & $S(\%)$ & $\mathrm{U}(\%)$ & FCR (mg) & $\mathrm{pH}$ & $\begin{array}{l}\mathrm{NH}_{3}-\mathrm{N} \\
(\mathrm{mg} \%)\end{array}$ & $\begin{array}{l}\mathrm{HCN} \\
(\mathrm{mg} / \mathrm{l})\end{array}$ & $\begin{array}{l}\text { Protozoa } \\
\left(\times 10^{5} \mathrm{cell} / \mathrm{mL}\right)\end{array}$ \\
\hline T1 & 0 & 2 & 0 & 6.51 & 21.1 & 0.0053 & 5.5 \\
\hline T2 & 0 & 4 & 0 & 6.42 & 21.8 & 0.0051 & 5.6 \\
\hline Т3 & 1 & 2 & 0 & 6.48 & 20.8 & 0.0050 & 5.0 \\
\hline T4 & 1 & 4 & 0 & 6.54 & 21.9 & 0.0049 & 5.4 \\
\hline T5 & 2 & 2 & 0 & 6.53 & 20.7 & 0.0048 & 4.8 \\
\hline T6 & 2 & 4 & 0 & 6.55 & 21.6 & 0.0048 & 5.0 \\
\hline T7 & 0 & 2 & 200 & 6.31 & 21.3 & 0.0058 & 5.2 \\
\hline T8 & 0 & 4 & 200 & 6.36 & 22.0 & 0.0059 & 5.7 \\
\hline T9 & 1 & 2 & 200 & 6.28 & 20.6 & 0.0055 & 5.0 \\
\hline T10 & 1 & 4 & 200 & 6.36 & 21.6 & 0.0054 & 4.9 \\
\hline T11 & 2 & 2 & 200 & 6.30 & 20.7 & 0.0047 & 5.3 \\
\hline T12 & 2 & 4 & 200 & 6.32 & 21.7 & 0.0046 & 5.6 \\
\hline T13 & 0 & 2 & 300 & 6.30 & 20.6 & 0.0074 & 5.2 \\
\hline T14 & 0 & 4 & 300 & 6.34 & 22.1 & 0.0076 & 5.4 \\
\hline T15 & 1 & 2 & 300 & 6.28 & 21.1 & 0.0057 & 4.8 \\
\hline T16 & 1 & 4 & 300 & 6.35 & 21.5 & 0.0056 & 5.3 \\
\hline T17 & 2 & 2 & 300 & 6.31 & 21.1 & 0.0049 & 5.4 \\
\hline T18 & 2 & 4 & 300 & 6.34 & 21.8 & 0.0048 & 5.5 \\
\hline T19 & 0 & 2 & 400 & 6.15 & 20.1 & 0.0088 & 5.5 \\
\hline Т20 & 0 & 4 & 400 & 6.22 & 21.8 & 0.0091 & 5.3 \\
\hline Т21 & 1 & 2 & 400 & 6.18 & 20.7 & 0.0076 & 5.5 \\
\hline T22 & 1 & 4 & 400 & 6.22 & 22 & 0.0079 & 5.8 \\
\hline Т23 & 2 & 2 & 400 & 6.19 & 21.1 & 0.0075 & 5.4 \\
\hline T24 & 2 & 4 & 400 & 6.25 & 21.6 & 0.0076 & 5.5 \\
\hline
\end{tabular}

$a, b, c, d$ means within column showed with different superscript letter accepted significantly different 


\begin{tabular}{|c|c|c|c|c|c|c|c|}
\hline Treatments & S (\%) & U (\%) & FCR (mg) & $\mathrm{pH}$ & $\begin{array}{l}\mathrm{NH}_{3}-\mathrm{N} \\
(\mathrm{mg} \%)\end{array}$ & $\begin{array}{l}\mathrm{HCN} \\
(\mathrm{mg} / \mathrm{l})\end{array}$ & $\begin{array}{l}\text { Protozoa } \\
\left(\times 10^{5} \mathrm{cell} / \mathrm{mL}\right)\end{array}$ \\
\hline SEM & & & & 0.12 & 0.09 & 0.001 & 0.27 \\
\hline \multicolumn{8}{|l|}{ S (\%) } \\
\hline 0 & & & & 6.32 & 21.41 & $0.006^{a}$ & 5.42 \\
\hline 1 & & & & 6.33 & 21.28 & $0.005^{b}$ & 5.31 \\
\hline 2 & & & & 6.35 & 21.28 & $0.005^{\mathrm{b}}$ & 5.21 \\
\hline P-Value & & & & 0.771 & 0.080 & $\nabla 0.0001$ & 0.231 \\
\hline \multicolumn{8}{|l|}{ U (\%) } \\
\hline 2 & & & & 6.31 & $20.84^{b}$ & 0.006 & 5.42 \\
\hline 4 & & & & 6.35 & $21.81^{a}$ & 0.006 & 5.36 \\
\hline P-Value & & & & 0.119 & $\bowtie 0.0001$ & 0.518 & 0.189 \\
\hline \multicolumn{8}{|l|}{ FCR (mg) } \\
\hline 0 & & & & $6.50^{\mathrm{a}}$ & 21.35 & $0.004^{d}$ & 5.21 \\
\hline 200 & & & & $6.32^{b}$ & 21.33 & $0.005^{c}$ & 5.29 \\
\hline 300 & & & & $6.31^{b}$ & 21.30 & $0.006^{b}$ & 5.26 \\
\hline 400 & & & & $6.20^{c}$ & 21.30 & $0.008^{a}$ & 5.50 \\
\hline P-Value & & & & $\bowtie 0.0001$ & 0.397 & $\nabla 0.0001$ & 0.406 \\
\hline \multicolumn{8}{|l|}{ Interaction } \\
\hline$S * U$ & & & & 0.961 & 0.002 & 0.634 & 0.140 \\
\hline$S^{*} F C R$ & & & & 0.632 & 0.254 & $\varangle 0.0001$ & 0.804 \\
\hline U*FCR & & & & 0.036 & $\varangle 0.0001$ & 0.022 & 0.753 \\
\hline$S * U * F C R$ & & & & 0.213 & $\otimes 0.0001$ & 0.746 & 0.061 \\
\hline
\end{tabular}

\section{In vitro digestibility}


The effect of elemental sulfur, urea, and FCR on IVDMD, IVNDFD, and IVADFD was shown in Table 4. Elemental sulfur, urea, and FCR had no significant interaction effect on IVDMD, IVNDFD, and IVADFD ( $>$ > 0.05). Elemental sulfur supplementation significantly influenced IVDMD, IVNDFD, and IVADFD. The IVDMD, IVNDFD, and IVADFD were increased when elemental sulfur was increased. Urea levels did not affect the IVDMD, IVNDFD, and IVADFD (Table 4). 
Table 4

Effect of elemental sulfur (S), urea (U), and fresh cassava root (FCR) on in vitro dry matter (IVDMD), in vitro neutral detergent fiber degradability (IVNDFD), and in vitro acid detergent fiber degradability (IVADFD)

\begin{tabular}{|lllllll}
\hline Treatments & $\mathbf{S}(\%)$ & $\mathbf{U}$ & $\begin{array}{l}\text { FCR } \\
(\mathbf{m g})\end{array}$ & IVDMD & IVNDFD & IVADFD \\
\hline T1 & 0 & 2 & 0 & 59.56 & 50.17 & 27.59 \\
\hline T2 & 0 & 4 & 0 & 60.80 & 52.03 & 28.49 \\
\hline T3 & 1 & 2 & 0 & 61.64 & 52.18 & 27.58 \\
\hline T4 & 1 & 4 & 0 & 62.73 & 53.45 & 28.38 \\
\hline T5 & 2 & 2 & 0 & 62.65 & 52.03 & 28.65 \\
\hline T6 & 2 & 4 & 0 & 62.96 & 53.33 & 29.42 \\
\hline T7 & 0 & 2 & 200 & 59.69 & 49.62 & 28.46 \\
\hline T8 & 0 & 4 & 200 & 61.95 & 54.91 & 28.94 \\
\hline T9 & 1 & 2 & 200 & 63.98 & 53.63 & 28.70 \\
\hline T10 & 1 & 4 & 200 & 62.77 & 54.51 & 29.29 \\
\hline T11 & 2 & 2 & 200 & 62.60 & 51.43 & 30.27 \\
\hline T12 & 2 & 4 & 400 & 63.07 & 54.05 & 30.51 \\
\hline T13 & 2 & 4 & 200 & 63.58 & 53.84 & 31.34 \\
\hline T14 & 0 & 2 & 300 & 60.82 & 51.45 & 29.47 \\
\hline T15 & 0 & 4 & 300 & 62.18 & 54.79 & 30.01 \\
\hline T16 & 1 & 2 & 300 & 62.48 & 53.66 & 29.81 \\
\hline T17 & 1 & 4 & 300 & 63.01 & 54.35 & 30.47 \\
\hline T18 & 2 & 2 & 300 & 63.44 & 53.44 & 31.16 \\
\hline T19 & 4 & 300 & 60.80 & 55.94 & 31.86 \\
\hline T20 & 2 & 400 & 61.30 & 50.29 & 28.94 \\
\hline T21 & 4 & 400 & 62.69 & 53.66 & 29.62 \\
\hline T22 & 2 & 400 & 62.21 & 54.35 & 29.21 \\
\hline T23 & 4 & 400 & 62.79 & 51.61 & 29.64 \\
\hline T24 & 400 & 63.07 & 54.05 & 30.25 \\
\hline & 2 & 4 & & & \\
\hline
\end{tabular}

a,b,c means within column showed with different superscript letter accepted significantly different 


\begin{tabular}{|c|c|c|c|c|c|c|}
\hline Treatments & S (\%) & $\begin{array}{l}\text { U } \\
\text { (\%) }\end{array}$ & $\begin{array}{l}\text { FCR } \\
\text { (mg) }\end{array}$ & IVDMD & IVNDFD & IVADFD \\
\hline SEM & & & & 0.75 & 1.32 & 0.27 \\
\hline \multicolumn{7}{|l|}{ S (\%) } \\
\hline 0 & & & & $60.82^{b}$ & $52.15^{b}$ & $29.51^{b}$ \\
\hline 1 & & & & $62.68^{a}$ & $53.78^{a}$ & $29.71^{b}$ \\
\hline 2 & & & & $63.06^{\mathrm{a}}$ & $53.21^{a}$ & $30.51^{\mathrm{a}}$ \\
\hline P-Value & & & & $\bowtie 0.0001$ & 0.044 & $\bigotimes 0.0001$ \\
\hline \multicolumn{7}{|l|}{ U (\%) } \\
\hline 2 & & & & $61.48^{b}$ & $51.95^{b}$ & $29.65^{b}$ \\
\hline 4 & & & & $62.50^{\mathrm{a}}$ & $54.14^{\mathrm{a}}$ & $30.17^{a}$ \\
\hline P-Value & & & & 0.009 & 0.0005 & 0.0001 \\
\hline \multicolumn{7}{|l|}{ FCR (mg) } \\
\hline 0 & & & & 61.72 & 52.20 & 29.80 \\
\hline 200 & & & & 62.42 & 52.99 & 30.03 \\
\hline 300 & & & & 62.56 & 54.02 & 30.05 \\
\hline 400 & & & & 62.06 & 52.99 & 29.76 \\
\hline P-Value & & & & 0.067 & 0.158 & 0.159 \\
\hline \multicolumn{7}{|l|}{ Interaction } \\
\hline$S * U$ & & & & 0.029 & 0.150 & 0.669 \\
\hline$S * F C R$ & & & & 0.644 & 0.959 & 0.714 \\
\hline$U \star F C R$ & & & & 0.775 & 0.845 & 0.953 \\
\hline$S * U * F C R$ & & & & 0.341 & 0.972 & 0.956 \\
\hline
\end{tabular}

\section{Ruminal volatile fatty acid concentration}

The effect of FCR, elemental sulfur, and urea levels on total VFA and their molar portions were shown in Table 5. Interaction between sulfur, urea, and FCR levels was not found for total VFA, C2, C3, and C4 
concentrations. Elemental sulfur supplementation significantly affected the $\mathrm{C} 3$ concentration but did not affect the total VFA, $\mathrm{C} 2$, and $\mathrm{C} 4$ concentration. The $\mathrm{C} 3$ concentration was increased significantly with the increase of elemental sulfur supplementation, this could be due to the change of VFA products pattern, mainly a decrease of $\mathrm{C} 2$ and increase of $\mathrm{C} 3$ concentration. Urea levels significantly affected the total VFA but did not influence their molar portions. FCR supplementation significantly affected the total VFA and their molar portions (Table 5). 
Table 5

Effect of elemental sulfur (S), urea (U), and fresh cassava root (FCR) on total volatile fatty acid (VFA) and their molar portions

\begin{tabular}{|c|c|c|c|c|c|c|c|c|}
\hline \multirow[t]{2}{*}{ Treatments } & \multirow[t]{2}{*}{$\mathrm{S}(\%)$} & $\mathbf{U}$ & FCR (mg) & Total VFA & $\mathrm{C} 2$ & C3 & & $\mathrm{C} 2: \mathrm{C} 3$ \\
\hline & & \multicolumn{3}{|c|}{ (\%) } & \multicolumn{4}{|c|}{ mole/100mol } \\
\hline T1 & 0 & 2 & 0 & 74.81 & 68.68 & 20.97 & 10.35 & 3.28 \\
\hline T2 & 0 & 4 & 0 & 74.38 & 68.46 & 21.26 & 10.29 & 3.23 \\
\hline T3 & 1 & 2 & 0 & 75.21 & 67.89 & 22.50 & 10.42 & 3.02 \\
\hline $\mathrm{T} 4$ & 1 & 4 & 0 & 74.73 & 68.12 & 21.77 & 10.30 & 3.13 \\
\hline T5 & 2 & 2 & 0 & 74.74 & 67.53 & 25.43 & 10.53 & 2.66 \\
\hline T6 & 2 & 4 & 0 & 74.35 & 68.41 & 25.09 & 10.50 & 2.73 \\
\hline T7 & 0 & 2 & 200 & 76.21 & 65.44 & 23.54 & 10.53 & 2.78 \\
\hline T8 & 0 & 4 & 200 & 75.74 & 66.69 & 22.66 & 10.64 & 2.94 \\
\hline T9 & 1 & 2 & 200 & 77.41 & 65.43 & 26.57 & 10.50 & 2.46 \\
\hline T10 & 1 & 4 & 200 & 77.11 & 67.11 & 25.91 & 10.64 & 2.59 \\
\hline T11 & 2 & 2 & 200 & 78.21 & 66.78 & 28.45 & 10.78 & 2.35 \\
\hline T12 & 2 & 4 & 200 & 77.76 & 67.19 & 27.06 & 10.75 & 2.49 \\
\hline T13 & 0 & 2 & 300 & 77.30 & 64.00 & 28.91 & 10.59 & 2.21 \\
\hline T14 & 0 & 4 & 300 & 75.90 & 64.17 & 26.83 & 10.50 & 2.39 \\
\hline T15 & 1 & 2 & 300 & 82.72 & 64.31 & 29.12 & 10.57 & 2.21 \\
\hline T16 & 1 & 4 & 300 & 80.74 & 65.11 & 28.17 & 10.72 & 2.31 \\
\hline T17 & 2 & 2 & 300 & 85.72 & 64.04 & 29.89 & 10.63 & 2.14 \\
\hline T18 & 2 & 4 & 300 & 85.24 & 65.07 & 29.82 & 10.60 & 2.18 \\
\hline T19 & 0 & 2 & 400 & 74.22 & 65.48 & 24.25 & 10.27 & 2.77 \\
\hline T20 & 0 & 4 & 400 & 73.74 & 66.28 & 25.52 & 10.71 & 2.60 \\
\hline T21 & 1 & 2 & 400 & 75.22 & 62.30 & 26.73 & 10.98 & 2.33 \\
\hline T22 & 1 & 4 & 400 & 74.24 & 64.37 & 25.12 & 10.51 & 2.56 \\
\hline T23 & 2 & 2 & 400 & 76.22 & 64.35 & 25.11 & 10.54 & 2.56 \\
\hline
\end{tabular}

C2 means acetic acid; C3 means propionic acid; C4 means butyric acid

a,b,c means within column showed with different superscript letter accepted significantly different 


\begin{tabular}{|c|c|c|c|c|c|c|c|c|}
\hline \multirow[t]{2}{*}{ Treatments } & \multirow[t]{2}{*}{ S (\%) } & U & FCR (mg) & Total VFA & C2 & C3 & & C2:C3 \\
\hline & & \multicolumn{3}{|c|}{ (\%) } & \multicolumn{3}{|c|}{ mole/100mol } & \\
\hline T24 & 2 & 4 & 400 & 75.74 & 63.15 & 25.80 & 11.05 & 2.46 \\
\hline SEM & & & & 3.37 & 1.86 & 2.70 & 2.22 & 0.32 \\
\hline \multicolumn{9}{|l|}{ S (\%) } \\
\hline 0 & & & & 75.23 & 66.15 & $23.92^{c}$ & 9.54 & 2.77 \\
\hline 1 & & & & 77.17 & 65.57 & $25.67^{b}$ & 8.62 & 2.56 \\
\hline 2 & & & & 78.49 & 65.81 & $27.73^{a}$ & 7.16 & 2.45 \\
\hline P-Value & & & & 0.421 & 0.617 & $\bowtie 0.0001$ & 0.063 & 0.081 \\
\hline \multicolumn{9}{|l|}{ U (\%) } \\
\hline 2 & & & & $76.59^{b}$ & 66.18 & 25.60 & 8.40 & 2.63 \\
\hline 4 & & & & $77.33^{a}$ & 65.52 & 25.96 & 8.49 & 2.55 \\
\hline P-Value & & & & 0.008 & 0.174 & 0.337 & 0.872 & 0.146 \\
\hline \multicolumn{9}{|l|}{ FCR (mg) } \\
\hline 0 & & & & $74.70^{c}$ & $68.18^{a}$ & $22.75^{\mathrm{C}}$ & $8.98^{a b}$ & $2.98^{a}$ \\
\hline 200 & & & & $77.08^{b}$ & $66.43^{b}$ & $26.23^{b}$ & $7.78^{\mathrm{bc}}$ & $2.60^{\mathrm{b}}$ \\
\hline 300 & & & & $81.19^{a}$ & $64.45^{\mathrm{c}}$ & $28.54^{a}$ & $6.75^{c}$ & $2.24^{c}$ \\
\hline 400 & & & & $74.89^{c}$ & $64.32^{c}$ & $25.56^{\mathrm{b}}$ & $10.26^{a}$ & $2.54^{b}$ \\
\hline P-Value & & & & $\bowtie 0.0001$ & $\varangle 0.0001$ & $\bowtie 0.0001$ & 0.0004 & $₫ 0.0001$ \\
\hline \multicolumn{9}{|l|}{ Interaction } \\
\hline$S * U$ & & & & 0.717 & 0.713 & 0.884 & 0.996 & 0.436 \\
\hline $\mathrm{S} * \mathrm{FCR}$ & & & & $\bowtie 0.0001$ & 0.449 & 0.017 & 0.018 & 0.249 \\
\hline U*FCR & & & & 0.437 & 0.939 & 0.980 & 0.904 & 0.772 \\
\hline$S * U * F C R$ & & & & 0.958 & 0.908 & 0.864 & 0.791 & 0.861 \\
\hline \multicolumn{9}{|c|}{ C2 means acetic acid; C3 means propionic acid; C4 means butyric acid } \\
\hline
\end{tabular}




\section{Discussion}

\section{Gas kinetics and total gas}

The $b$ value represents the gas produced from the insoluble fraction. Therefore, the increase of the $b$ value suggested that sulfur supplementation could improve the digestion of fiber. Morrison et al. [13] stated that sulfur supplementation could improve the microbial activity in the rumen, mainly anaerobic fungi by stimulating the excretion of the fibrous breakdown enzyme. A similar result was reported by Promkot et al. [6] who, significantly found an increase of the $b$ value when increased sulfur supplementation up to $1 \%$ in substrate containing cassava (foliage and hay). Urea levels in concentrate significantly increased the potential extent of gas production $(a+b)$, in which $4 \%$ urea showed significantly higher than $2 \%$ urea. A similar finding was reported by Lunsin et al. [14] who found $5 \%$ urea increased the $a+b$ value compared to $0 \%$ urea. However, the mechanism of this improvement is not clear. Hameed et al. [15] assumed that the greater kinetics of gas could be contributed by the greater structural carbohydrate degradation with urea treatment, which could clearly see a greater in vitro NDF and ADF degradability when increased urea levels (Table 4). FCR supplementation significantly affected the kinetics of gas except the $a+b$ value and total gas (Table 2). Increasing FCR supplementation significantly increased gas produced from immediate soluble fraction (a), b value, gas production rate constant for insoluble fraction (c), and total gas; whereas the highest kinetics of gas and total gas was found with $300 \mathrm{mg}$ of FCR supplementation. This could be explained by the more available carbohydrate as FCR increased came to the rumen for microbial fermentation resulting in greater kinetics of gas and total gas. Promkot et al. [6] used cassava foliage and hay in the substrate did not affect the kinetics of gas and total gas, this might be due to the low soluble carbohydrate content in cassava foliage and hay compared to the FCR. Dagaew et al. [16] reported that reduced FCR levels in the substrate significantly decreased the kinetics of gas and total gas.

\section{Ruminal fermentation, hydrogen cyanide concentration, and protozoal number}

The reduction of the HCN could be explained by the action of rhodanese enzyme presented in the rumen that converts $\mathrm{HCN}$ into a less toxic substance (thiocyanate) and excreted out via urine $[5,6]$. Promkot et al. [6] found that an increase of sulfur supplementation at 0.5 and $1 \%$ into the fresh cassava foliage substrate showed a great in vitro disappearance of $\mathrm{HCN}$ compared to $0.2 \%$ of sulfur supplementation. Similarly, Dagaew et al. [16] added sulfur into feed-block at 2 and $4 \%$ with FCR supplementation showed a significant decrease of the in vitro HCN concentration. Promkot and Wanapat [7] found an increase of milk thiocyanate in dairy cows fed fresh cassava foliage and hay when increased sulfur supplementation from 0.15 to $0.4 \%$. Supapong and Cherdthong [5] found a significant increase in milk thiocyanate concentration in dairy cows fed a total mixed ration containing FCR when increased sulfur supplementation from $1-2 \%$. Urea levels significantly influenced the $\mathrm{NH}_{3}-\mathrm{N}$ concentration but did not affect $\mathrm{pH}, \mathrm{HCN}$ concentration, and protozoal number. Increasing urea significantly increased the concentration of $\mathrm{NH}_{3}-\mathrm{N}$, this could be due to the activity of urease enzyme produced by the ruminal microbes to degrade urea into ammonia which, subsequently used for microbial protein synthesis [9]. Supapong and Cherdthong [5] found a significantly higher $\mathrm{NH}_{3}-\mathrm{N}$ concentration with $2.5 \%$ than $1.25 \%$ 
urea in dairy cows fed total mixed ration. Wanapat et al. [17] fed dairy cows with $5.5 \%$ urea-treated rice straw resulting in the highest $\mathrm{NH}_{3}-\mathrm{N}$ concentration when compared to the control and $2.2 \%$ urea treatment. FCR supplementation significantly affected the ruminal $\mathrm{pH}$ and $\mathrm{HCN}$ concentration but did not affect $\mathrm{NH}_{3}-\mathrm{N}$ and protozoal numbers (Table 3). An increase in FCR supplementation significantly decreased the ruminal $\mathrm{pH}$ while increased the $\mathrm{HCN}$ concentration. A decrease of ruminal $\mathrm{pH}$ when increased FCR supplementation could be due to the accumulation of lactic acid from carbohydrate fermentation by ruminal microbes. The greater lactate accumulation led to a lower $\mathrm{pH}$ in the rumen. As FCR contained HCN, therefore increase of FCR supplementation in the substrate resulted in the greater $\mathrm{HCN}$ concentration in the ruminal fluid. Dagaew et al. [16] varied FCR ratio with rice straw did not affect the ruminal $\mathrm{pH}$ but significantly increased the ruminal $\mathrm{HCN}$ concentration. Cherdthong et al. [2] fed FCR at 1 and $1.5 \%$ body weight did not change the ruminal $\mathrm{pH}$ of Thai native beef cattle but significantly increased the blood thiocyanate concentration after $4 \mathrm{~h}$ post-feeding. Promkot and Wanapat [7] fed dairy cows with cassava foliage and hay did not alter the ruminal $\mathrm{pH}$ but significantly increased the serum and milk thiocyanate.

\section{In vitro digestibility}

The interaction effect of elemental sulfur, urea, and FCR has never been evaluated until the present. However, the interaction effect of elemental sulfur and FCR have been evaluated and found no interaction effect on both in vitro and in vivo studies [2, 16]. Supapong and Cherdthong [5] evaluated the interaction effect of elemental sulfur and urea and found no interaction effect on digestibility. Elemental sulfur supplementation significantly influenced IVDMD, IVNDFD, and IVADFD. The IVDMD, IVNDFD, and IVADFD were increased when elemental sulfur was increased. The increase of IVDMD, IVNDFD, and IVADFD might be due to the benefits of sulfur in enhancing the ruminal microbial activity on digestion. Slyter et al. [18] stated that sulfur could increase cellulolytic bacteria, and may improve fiber degradability. Dagaew et al. [16] found a significant increase of IVDMD with feed-block containing elemental sulfur but did not found a significant effect on IVNDFD and IVADFD. Similarly, Cherdthong et al. [2] found significant increased apparent DM digestibility in Thai native beef cattle fed feed-block containing sulfur but did not found for apparent fiber digestibility. Promkot et al. [6] revealed an increase of in vitro true digestibility with sulfur supplementation in substrate containing both cassava foliage and hay. A later study by Promkot and Wanapat [7] in dairy cows found that sulfur supplementation significantly affected only DM digestibility but did not affect the fiber digestibility. Urea levels did not affect the IVDMD, IVNDFD, and IVADFD (Table 4). A similar finding was reported by Boucher et al. [19] who found no change of nutrient digestibility with urea supplementation into corn silage diet for dairy cows. The lack of urea effect on in vitro degradability in this study could be related to the maximum ruminal $\mathrm{NH}_{3}-\mathrm{N}$ concentration to support the maximal ruminal digestibility. The $\mathrm{NH}_{3}-\mathrm{N}$ concentration in this study ranged from 20 to $21 \mathrm{mg} / \mathrm{dl}$ (Table 3). Boucher et al. [19] found that $9 \mathrm{mg} / \mathrm{dl}$ of ruminal $\mathrm{NH}_{3}-\mathrm{N}$ would be more than adequate for supporting the maximal ruminal DM digestibility. Kang-Meznarich and Broderick [20] revealed that 3.3 $\mathrm{mg} / \mathrm{dl}$ was adequate for the maximal DM digestibility in non-lactating dairy cows fed pelleted diet. Chanjula and Ngampongsai [21] found that increase in urea supplementation (0 to 3\%) in concentration did not affect the apparent nutrient digestibility in growing goats fed elephant grass. FCR 
supplementation did not affect the IVDMD, IVNDFD, and IVADFD (Table 4). Promkot et al. [6] found that used cassava foliage and hay in the substrate did not affect the in vitro true digestibility. A later study by Promkot and Wanapat [7] similarly found no effect of cassava foliage and hay on apparent nutrient digestibility in dairy cows. Cherdthong et al. [2] found that 1 and $2 \%$ cassava root supplementation did not affect the apparent nutrient digestibility in Thai native beef cattle.

\section{Ruminal volatile fatty acid concentration}

The interaction effect of elemental sulfur, urea, and FCR was the lack in the literature until the present. However, the interaction effect of elemental sulfur and urea has been evaluated and found no interaction effect on total VFA and their molar portions [5]. And the interaction effect of FCR and sulfur has been reported by Dagaew et al. [16] and Cherdthong et al. [2] who found no interaction effect between sulfur and FCR on total VFA and their molar concentration. Elemental sulfur supplementation significantly affected the $\mathrm{C} 3$ concentration but did not affect the total VFA, C2, and C4 concentration. The C3 concentration was increased significantly with the increase of elemental sulfur supplementation, this could be due to the change of VFA products pattern, mainly a decrease of C2 and increase of C3 concentration. Thompson et al. [22] revealed that dietary containing sulfur decreased the $\mathrm{C} 2$ to $\mathrm{C} 3$ ratio resulting in a greater C3 concentration. Dagaew et al. [16] found an increase of in vitro C3 concentration when increased sulfur levels in the feed-block. Supapong and Cherdthong [5] found an increase of ruminal C3 concentration with sulfur supplementation at 1 and $2 \%$ in dairy cows fed a total mixed ration containing FCR. Promkot et al. [6] found a trend in increasing ruminal C3 concentration in dairy cows fed cassava foliage and hay in the diet. Urea levels significantly affected the total VFA but did not influence their molar portions (Table 5). An increase of urea showed an increase in the total VFA. This may be due to the effect of urea on carbohydrate metabolism in the rumen. Obara [23] revealed that used urea as a nitrogen source could enhance the ruminal microbes' activity to digest carbohydrates resulting the greater VFA production. Similar findings for an increase of total VFA with urea treatment have been reported [5]. FCR supplementation significantly affected the total VFA and their molar portions (Table 5). The total VFA and C3 concentration were increased when increased the FCR supplementation; in contrast, C2 and C4 were decreased when increased the FCR supplementation. The higher total VFA and C3 concentration and lower $\mathrm{C} 2$ and $\mathrm{C} 4$ concentration were found in substrate containing FCR compared to the control. Increasing C3 concentration normally decreases the C2 and C4 concentration in the rumen because most carbohydrate fermentation by microbes in the rumen resulting in the greater $\mathrm{C} 3$ concentration. Notably, the increase of FCR up to $400 \mathrm{mg}$ significantly decreased the total VFA and C3 concentration while significantly increased C4 concentration when compared with the $300 \mathrm{mg}$ of FCR supplementation. This might be due to the negative effect of $\mathrm{HCN}$ on ruminal microbes' activity when supplemented up to 400 $\mathrm{mg}$ of the total substrate. Cherdthong et al. [2] found an increase of the $\mathrm{C} 3$ concentration in Thai native beef cattle when increased cassava root from 1 to $2 \%$ of body weight. Similarly, Dagaew et al. [16] found an increase of the in vitro $\mathrm{C} 3$ concentration when increased FCR ratio with rice straw in the substrate.

\section{Conclusions}


The study found that elemental sulfur, urea, and FCR had no interaction effect on the kinetics of gas, total gas, ruminal fermentation, and $\mathrm{HCN}$ concentration. Elemental sulfur supplementation significantly increased the gas produced from insoluble fraction, in vitro degradability, and C3 concentration while decreased the ruminal $\mathrm{HCN}$ concentration. Urea levels showed a significant increase in the potential extent of gas production, ruminal $\mathrm{NH}_{3}-\mathrm{N}$, and total VFA. FCR supplementation significantly increased the kinetics of gas except for the potential extent of gas and total gas, total VFA, C3 concentration, and HCN while decreased ruminal $\mathrm{pH}, \mathrm{C} 2$, and $\mathrm{C} 4$ concentration. It could be concluded that $2 \%$ elemental sulfur, $4 \%$ urea, and $300 \mathrm{mg}$ FCR showed a greater effect on gas production, ruminal fermentation, and HCN reduction. However, in vivo study is needed to be conducted to elucidate their further effect.

\section{Methods}

Animal ethics approval (ACUC-KKU 32/61) was issued to ensure standard care of animals during the study.

\section{Experimental design and treatments}

A $3 \times 2 \times 4$ in a completely randomized design were conducted. Factor $A$ was level of sulfur at $0 \%, 1 \%$, and $2 \%$ of concentrate dry matter (DM), factor $B$ was level of urea at $2 \%$ and $4 \%$ of concentrate $D M$, and factor $C$ was level of the FCR at 0, 200, 300, and $400 \mathrm{mg}$ of the total substrate. The FCR (Manihot esculenta Kasetsart 50) at one-year-old of age was purchased from a local supplier located in Khon Kaen province, Thailand. Sulfur and urea were purchased commercially.

\section{Substrate preparation}

The substrates including rice straw and concentrate mixture were dried at $60^{\circ} \mathrm{C}$ and ground to pass a 1$\mathrm{mm}$ sieve (Cyclotech Mill, Tecator, Sweden), while FCR was used as a fresh form. The ground samples of FCR, rice straw, and concentrate mixture were used to analyze DM (ID 967.03), organic matter (OM, ID 942.05), and crude protein (CP, ID 984.13) using the method of AOAC [24], neutral detergent fiber (NDF) and acid detergent fiber (ADF) according to Van Soest et al. [25]. Content of HCN in FCR was analyzed by using spectrophotometry (SpectroSC, LaboMed, inc, USA) with the 2,4-quinolinediol-pyridine reagent [26]. The concentrate ingredients and chemical compositions of concentrate, rice straw, and FCR used in this study were provided in Table 1.

\section{Animals and rumen fluid provision}

Two male rumen-fistulated dairy steers with body weight (BW) of $400 \pm 50 \mathrm{~kg}$ were raised in a separate pen with accessible clean water and fed concentrate at $0.5 \% \mathrm{BW} /$ day. The concentrate was formulated to have $12 \%$ CP following the recommendation of NRC [27]. Rice straw was daily fed ad libitum. The feeding lasted for 14-days before ruminal fluid was collected. After 14-days of feeding, approximately $1500 \mathrm{~mL}$ of ruminal fluid were manually collected and filtered through cheesecloth (four-layers) into pre-warmed thermos flasks, then immediately transferred to the laboratory. 
The inoculum was made of the ruminal fluid and artificial saliva. The artificial saliva was prepared according to Menke and Steingass [28]. A 1:2 ratio of ruminal fluid and artificial saliva was mixed in a thermos flask to form the inoculum, warmed at $39^{\circ} \mathrm{C}$, and continuously supplied with carbon dioxide. A 369 serum bottles ( $150 \mathrm{ml}$ volume) were prepared, in which 72 serum bottles with 3 bottles for blank were used to study the kinetics of gas, 147 bottles used to study ruminal fermentation ( $\mathrm{pH}$, ammonia nitrogen$\mathrm{NH}_{3}-\mathrm{N}$, volatile fatty acid- VFA, and protozoa) at 4 and $6 \mathrm{~h}$ of incubation, and 147 bottles used to study the degradability at 12 and $24 \mathrm{~h}$ of incubation. All treatments were done in three replications. The ground concentrate mixture and rice straw were weighed into the serum bottles at 50:50 ratio to obtain the final substrate of $500 \mathrm{mg}$. The ground FCR (fresh form) was weighed into the bottles at its respective levels of total substrate. A $50 \mathrm{ml}$ of artificial inoculum was withdrawn and injected into the serum bottles containing their respective treatments' substrate. The bottles were then transferred to the water bath with pre-set temperature of $39^{\circ} \mathrm{C}$ and incubated at various time series.

\section{Sample collection and analysis}

The gas produced from fermentation was manually measured using a pressure transducer syringe at 0 , $0.5,1,2,4,6,8,12,18,24,48,72$, and $96 \mathrm{~h}$ of incubation. The amount of gas at each time of incubation was fitted to the gas equation of Ørskov and McDonald [29] to study the kinetics of gas as follows:

$y=a+b\left[1-e^{(-c t)}\right]$

where $a$ is the gas production from the immediately soluble

fraction, $\mathrm{b}$ is the gas production from the insoluble fraction, $\mathrm{c}$ the gas production rate constant for the insoluble fraction (b), $a+b$ is the potential extent of gas production, and $t$ the incubation time.

After incubated for 4 and $6 \mathrm{~h}$, the pH was measured using a Hanna pH meter (model HI83141, HANA instruments, Romania) from 147 bottles, and the liquid samples were then filtered through cheesecloth (four-layers) and centrifuged at $16,000 \times g$ for $15 \mathrm{~min}$. After centrifuged, the supernatant was collected by dividing into two parts: the first part was used to analyzed $\mathrm{NH}_{3}-\mathrm{N}$ concentration using Kjeldahl methods according to AOAC [24] and VFA proportions including acetate (C2), propionate (C3), and butyrate (C4) using high-performance liquid chromatography (Instruments by controller water model 600E, Water model 484 UV detector, column Novapak C18, column size $4 \times 150 \mathrm{~mm}$, mobile phase $10 \mathrm{mM} \mathrm{H}_{2} \mathrm{PO}_{4}(\mathrm{pH}$ 2.5); ETL Testing Laboratory, Inc., Cortland, NY). The remaining part was mixed with formaldehyde at 1:9 ratio for protozoal counts using microscopic (Boeco, Hamburg, Germany). HCN concentration in the liquid samples was measured by using spectrophotometry [26].

After incubated for $12 \mathrm{~h}$ and $24 \mathrm{~h}$, the samples were collected by filtering through pre-weighed Gooch crucibles, then the Gooch crucibles containing sample were oven-dried at $60^{\circ} \mathrm{C}$ for $24 \mathrm{~h}$. After oven-dried, the DM of samples and blank was used to calculate the in vitro DM degradability (IVDMD) [30]. Then, the samples were analyzed for in vitro NDF, and ADF degradability according to Van Soest et al. [25].

\section{Statistical analysis}


All data were subjected to the General Linear Models (GLM) procedures of SAS [31]. The following model was used:

$y_{i j k l}=\mu+a_{i}+b_{j}+c_{k}+a b_{i j}+a c_{i k}+b c_{j k}+a b c_{i j k}+\bigotimes_{i j k l}$

where $y$ is the observation, $m$ is the overall mean, $a_{i}$ is the level of sulfur(i,1-3), $b_{j}$ is the level of urea $(j, 1-$ $2), c_{k}$ is the level of FCR at $0 \%, 40 \%, 60 \%$ and $80 \%$ of all diet $(k, 1-4), a b_{i j}, a c_{i k}, b c_{j k}, a b c_{i j k}$, is the interaction effect and $\mathbb{V}_{\mathrm{ijkl}}$ is the error. Differences among treatment means for all parameters were contrasted by Tukey's Multiple Comparison Test. Differences among means were accepted at $\mathrm{P}<0.05$.

\section{Abbreviations}

${ }^{\circ} \mathrm{C}$

ADF

AOAC

$\mathrm{C} 2$

C3

C4

$\mathrm{CH} 4$

$\mathrm{CP}$

DM

FCR

$\mathrm{HCN}$

IVADFD

IVNDFD

IVDMD

$\mathrm{N}$

NDF

$\mathrm{OM}$
Degree celsius

Acid detergent fiber

The Association of Official Analytical Chemists

Acetate

Propionate

Butyrate

Methane

Crude protein

Dry matter

Fresh cassava root

Hydrogen cyanide

In vitro acid detergent fiber degradability

In vitro neutral detergent fiber degradability

In vitro dry matter

Nitrogen

Neutral detergent fiber

Organic matter 


\section{Declarations}

\section{Ethics approval and consent to participate}

The study was approved by the Khon Kaen University Animal Ethics Committee (Record No. ACUC-KKU 32/61). Our study confirmed that all methods were performed in accordance with the relevant guidelines and regulations. The study was carried out in compliance with the ARRIVE guidelines.

\section{Consent for publication}

Not applicable.

\section{Availability of data and materials}

The dataset generated and/or analyzed during the current study is not publicly available since the data is a preliminary part of another study. The data is, however, available from the corresponding author on reasonable request.

\section{Competing interests}

The authors declare that they have no competing interests.

\section{Funding}

This study was granted by Animal Feed Inter Trade Co., Ltd and Thailand Science Research and Innovation (TSRI) through the Research and Researchers for Industries (RRi) Programme (contract grant RRI-PHD60I0015).

\section{Authors' contributions}

PS and AC designed the experiments. PS, AC, and SS draft the first vision of the manuscript. PS performed the experiment. PS, AC, and SS recorded and analyzed data. PS, AC, and SS participated in preparation of the manuscript, especially interpreted the results. PS, AC, SS, and MW discussed and prepared the final report. All of the authors have read and approved the final manuscript.

\section{Acknowledgements}


This work was supported by the the Increase Production Efficiency and Meat Quality of Native Beef and Buffalo Research Group, the Tropical Feed Resources Research and Development Center (TROFREC), Khon Kaen University (KKU), Department of Animal Science, Faculty of Agriculture, KKU.

\section{References}

1. Wanapat M, Khampa S. Effect of levels of supplementation of concentrate containing high levels of cassava chip on rumen ecology, microbial $\mathrm{N}$ supply and digestibility of nutrients in beef cattle. AsianAustralas J Anim Sci. 2007;20:75-81. https://doi.org/10.5713/ajas.2007.75.

2. Cherdthong A, Khonkhaeng B, Seankamsorn A, Supapong C, Wanapat M, Gunun N, Polyorach S. Effects of feeding fresh cassava root with high-sulfur feed block on feed utilization, rumen fermentation, and blood metabolites in Thai native cattle. Trop Anim Health Prod. 2018;50:1365-71. http://doi.org/ 1007/s11250-018-1569-8.

3. Aminlari, M. D18 Distribution of the cyanide metabolizing enzyme rhodanese in different tissues of domestic animals. J Vet Pharmacol Therapeut.2006;29:128-8. https://doi.org/10.1111/j.13652885.2006.00762_20.x.

4. Supapong $C$, Cherdthong A, Wanapat M, Chanjula P, Uriyapongson S. Effects of sulfur levels in fermented total mixed ration containing fresh cassava root on feed utilization, rumen characteristics, microbial protein synthesis, and blood metabolites in Thai native beef cattle. Animals. 2019;9:261. https://doi.org/10.3390/ani9050261.

5. Supapong C, Cherdthong A. Effect of sulfur concentrations in fermented total mixed rations containing fresh cassava root on rumen fermentation. Anim Prod Sci. 2020;60:1429-34. http://doi.org/10.1071/AN18779.

6. Promkot C, Wanapat M, Wachirapakorn C, Navanukraw C. Influence of sulfur on fresh cassava foliage and cassava hay incubated in rumen fluid of beef cattle. Asian-Australas J Anim Sci. 2007;20:1424-32.

7. Promkot $\mathrm{C}$, Wanapat $\mathrm{M}$. Effect of elemental sulfur supplementation on rumen environment parameters and utilization efficiency of fresh cassava foliage and cassava hay in dairy cattle. AsianAustralas J Anim Sci. 2009;22:1366-76. https://doi.org/10.5713/ajas.2007.1424.

8. Wanapat M, Kang S. Cassava chip (Manihot esculenta Crantz) as an energy source for ruminant feeding. Anim Nutr. 2015;1:266-70. https://doi.org/10.1016/j.aninu.2015.12.001.

9. Cherdthong A, Wanapat M, Wachirapakorn C. 2011. Influence of urea calcium mixture supplementation on ruminal fermentation characteristics of beef cattle fed on concentrates containing high levels of cassava chips and rice straw. J Anim Sci. 2011;163:43-51. https://doi.org/10.1016/j.anifeedsci.2010.10.003.

10. Johnson WH, Goodrich RD, Meiske, JC. 1971. Metabolism of radioactive sulfur from elemental sulfur, sodium sulfate and methionine by lambs. J Anim Sci. 1971;32:778-83.

https://doi.org/10.2527/jas1971.324778x. 
11. Bird PR. Sulphur Metabolism and Excretion Studies in Ruminants IX. Sulphur, Nitrogen, and Energy Utilization by Sheep Fed a Sulphur-Deficient and a Sulphate-Supplemented, Roughage-Based Diet. Aust J Biol Sci. 1972;25:1073-86. https://doi.org/10.1071/BI9721073.

12. National Research Council (NRC). Nutrient requirements of dairy cattle. 7th Ed. National Academic Press, Washington DC. 2000.

13. Morrison M, Murray RM, Boniface AN. Nutrient metabolism and rumen micro-organisms in sheep fed a poor-quality tropical grass hay supplemented with sulphate. J Agric Sci.1990;115:269-75. https://doi.org/10.1017/S0021859600075237.

14. Lunsin R, Wanapat M, Rowlinson P. Effect of cassava hay and rice bran oil supplementation on rumen fermentation, milk yield and milk composition in lactating dairy cows. Asian Australas J Anim Sci. 2012;25:1364-73. https://doi.org/10.3168/jds.S0022-0302(98)75598-5.

15. Hameed AA, Salih MA, El-Seed F. 2012. Effect of urea treatment on the chemical composition and rumen degradability of Groundnut Hull. Pak J Nutr. 2012;11:1146-51. https://doi.org/10.1016/S03017516(99)00077-0.

16. Dagaew G, Cherdthong A, Wanapat M, Chanjula P. In vitro rumen gas production kinetics, hydrocyanic acid concentration and fermentation characteristics of fresh cassava root and feed block sulfur concentration. Anim Prod Sci. 2020;60:659-64. https://doi.org/10.1071/AN18784.

17. Wanapat M, Polyorach S, Boonnop K, Mapato C, Cherdthong A. Effects of treating rice straw with urea or urea and calcium hydroxide upon intake, digestibility, rumen fermentation and milk yield of dairy cows. Livest Sci. 2009;125:238-43. https://doi.org/10.1016/j.livsci.2009.05.001.

18. Slyter LL, Chalupa W, Oltjen RR, Weaver JM. Sulfur influences on rumen microorganisms in vitro and in sheep and calves. J Anim Sci. 1986;63:1949-59.

19. Boucher SE, Ordway RS, Whitehouse NL, Lundy FP, Kononoff PJ, Schwab CG. 2007. Effect of incremental urea supplementation of a conventional corn silage-based diet on ruminal ammonia concentration and synthesis of microbial protein. J Dairy Sci. 2007;90:5619-33. http://doi.org/ 3168/jds.2007-0012.

20. Kang-Meznarich JH, Broderick G A. Effects of incremental urea supplementation on ruminal ammonia concentration and bacterial protein formation. J Anim Sci. 1980;51:422-31.

21. Chanjula P, Ngampongsai W. Effect of supplemental nitrogen from urea on digestibility, rumen fermentation pattern, microbial populations and nitrogen balance in growing goats. J Sci Technol. 2008;30:571-8.

22. Thompson LH, Wise MB, Harvey R., Barrick ER. Starea, urea and sulfur in beef cattle rations. J Anim Sci. 1972;35:474-80.

23. Obara Y. Changes of ruminal properties of sheep during feeding urea diet. Japan $\mathrm{J}$ Zootechnic Sci. 1975;46:140-5.

24. Official Method of Analysis, 16th ed. Animal Feeds: Association of Official Analytical Chemists, VA, USA. 1995. 
25. Van Soest PV, Robertson JB, Lewis B. Methods for dietary fiber, neutral detergent fiber, and nonstarch polysaccharides in relation to animal nutrition. J. Dairy Sci. 1991;74:3583-97. https://doi.org/10.3168/jds.S0022-0302(91)78551-2.

26. Lambert JL, Ramasamy J, Paukstelis JV. Stable reagents for the colorimetric determination of cyanide by modified Koenig reactions. Analyt Chem. 1975;47:916-8. https://doi.org/10.1021/ac60356a036.

27. National Research Council (NRC). Nutrient requirements of dairy cattle. 7th Ed. National Academic Press, Washington DC. 2001.

28. Menke KH. Estimation of the energetic feed value obtained from chemical analysis and in vitro gas production using rumen fluid. Anim Research and Develop. 1988;28:7-55.

29. Ørskov ER, McDonald I. The estimation of protein degradability in the rumen from incubation measurements weighted according to rate of passage. J Agriculture Sci. 1979;92:499-503.

30. Tilley JMA, Terry DR. A two-stage technique for the in vitro digestion of forage crops. Grass Forage Sci. 1963;18:104-11.

31. SAS/STAT User's Guide: Version 6. 12.4th edn. SAS Institute Inc., Cary, North Carolina. 1996. 